\title{
Safety and Efficacy of Corneal Crosslinking Treatment in Children with Keratoconus
}

\section{Keratokonuslu Çocuklarda Korneal Çapraz Bağlama Tedavisinin Güvenilirlik ve Etkinliği}

\author{
Deniz ÖZARSLAN ÖZCAN1ㅗ 1 (D), Sait Coşkun ÖZCAN ${ }^{1}$ (D) \\ ${ }^{1}$ Department of Ophthalmology, Hatay Mustafa Kemal University Tayfur Ata Sökmen Faculty of Medicine, Hatay, TURKEY
}

\begin{abstract}
Background: To evaluate the safety and efficacy of corneal crosslinking (CXL) treatment in children with keratoconus.

Materials and Methods: A total of 45 eyes of 34 children with progressive keratoconus were included in this study. CXL was performed according to the conventional method. Manifest refraction, uncorrected distance visual acuity (UDVA), corrected distance visual acuity (CDVA), corneal topography values, and endothelial cell density (ECD) were evaluated at baseline and 24month follow-up.

Results: The mean age of the patients was $14.6 \pm 3.5$ years. The mean spherical equivalent readings were statistically significantly decreased at 24 months $(p=0.016)$. There was a significant improvement in the mean UDVA and CDVA at 24 months ( $p=0.002, p=0.006$, respectively). The mean K1 and K2 were statistically significantly reduced at 24 months postoperatively $(p=0.004$, $p=0.006$, respectively). There was no significant alteration in ECD at any follow-up examination. No significant sight-threatening complications were observed.

Conclusions: The CXL procedure seem to be safe and effective in stabilizing keratoconus progression in children within a follow-up of 24 months.
\end{abstract}

Key Words: Corneal crosslinking, Keratoconus, Pediatric keratoconus

öz.

Amaç: Keratokonuslu çocuklarda korneal çapraz bağlama $(C X L)$ tedavisinin güvenilirlik ve etkinliğini değerlendirmek.

Materyal ve Metod: Bu çalışmaya ilerleyici keratokonuslu 34 çocuğun 45 gözü dahil edildi. CXL geleneksel yönteme göre yapıldı. Manifest kırılma, düzeltilmemiş uzak görme keskinliği (UDVA), düzeltilmiş uzak görme keskinliği (CDVA), korneal topografi değerleri ve endotel hücre yoğunluğu (ECD) başlangıçta ve 24 aylık takipte değerlendirildi.

Bulgular: Hastaların ortalama yaşı $14.6 \pm 3.5$ yıldı. Ortalama sferik eşdeğer değerler 24 . ayda istatistiksel olarak anlamlı şekilde azaldı $(p=0.016)$. Ortalama UDVA ve CDVA'da 24. ayda anlamlı bir iyileşme vardı (sırasıyla $p=0.002, p=0.006$ ). Ortalama K1 ve K2 ameliyat sonrası 24 . ayda istatistiksel olarak anlamlı şekilde azaldı (sırasıyla $p=0.004, p=0.006$ ). Herhangi bir takip muayenesinde ECD'de anlamlı bir değişiklik olmadı. Görmeyi tehdit eden önemli bir komplikasyon gözlenmedi.

Sonuç: CXL prosedürü, 24 aylık takip süresi içinde çocuklarda keratokonus progresyonunu stabilize etmede güvenli ve etkili görünmektedir.

Anahtar kelimeler: Kornea çapraz bağlanması, Keratokonus, Pediatrik keratokonus
Corresponding Author/Sorumlu Yazar

Dr. Deniz ÖZARSLAN ÖZCAN

Mustafa Kemal Üniversitesi Tayfur Ata Sökmen Tıp Fakültesi (31060) Alahan. Hatay, TURKEY

E-mail: deniz.0609@hotmail.com

Received / Geliş Tarihi: 22.02.2021

Accepted / Kabul Tarihi: 15.03.2021

DOI: $10.35440 /$ hutfd. 885032 


\section{Introduction}

Keratoconus is a progressive non-inflammatory disorder of the cornea leading to irregular astigmatism and loss of vision (1). The disease frequently begins during childhood and its incidence in the pediatric population under 14 years of age was determined to be $0.53 \%(2)$.

The youngest child with keratoconus reported in the literature was four years old (3). Family history and ocular allergy/eye rubbing are important risk factors for keratoconus. In children, the disease is frequently detected in more advanced stages with increased need for corneal transplant and it progresses rapidly $(4,5)$. Keratoconus treatment in pediatric cases is thus a very important, sensitive and challenging process.

The main treatment modalities for keratoconus consist of spectacles, contact lenses, corneal cross-linking (CXL), intracorneal ring segments and keratoplasty. CXL is the only treatment procedure that stops the worsening of keratoconus by increasing corneal cross-links and strengthening the cornea (6). The efficacy of CXL has been demonstrated in numerous studies in adult patients (7-9). However, the effectiveness and long-term results of CXL in children are controversial and may generate different responses from those in adults. In addition, there is no standard for a pediatric keratoconus treatment protocol and the timing of surgery.

We aimed to investigate the long-term efficacy and safety of CXL in children for the treatment of progressive keratoconus in this study.

\section{Materials and Methods}

This study included pediatric patients with progressive keratoconus who were treated with CXL at our university hospital. This study adhered to the tenets of the Declaration of Helsinki and was approved by the local Ethics Committee (Hatay Mustafa Kemal University non-interventional clinical research ethics committee Date:18/02/2021 Number:25/03) . An informed consent form was obtained from the parents of the patients.

Patients younger than 18 years of age with a thickness of more than $400 \mu \mathrm{m}$ at the thinnest location of the cornea and a confirmed keratoconus progression were enrolled into the study. The severity of the disease was evaluated using the Amsler-Krumeich classification (10). Patients with a history of keratitis, corneal scar and opacity, previous eye surgery, ocular infections, serious dry eye, and connective tissue diseases were excluded from the study. Contact lenses wearers stopped using the lenses two weeks before the treatment.

Manifest refraction, visual acuity, biomicroscopic evaluation, corneal topography (Sirius; CSO Inc, Italy) and specular microscopy (Topcon SP-3000P; Topcon Corp, Japan) were evaluated in a preoperative and a postoperative 24month examination. All measurements were taken at the same time of day (10:00-12:00 A.M.). The main outcome measurements included spherical, cylindrical and spheric equivalent (SE) refractive values, uncorrected distance visual acuity (UDVA), corrected distance visual acuity (CDVA),

pachymetry at the thinnest location, topographic parameters (K1,K2 and Kmean) and corneal endothelial cell density (ECD).

\section{Treatment Protocol}

The CXL procedure was performed by the same experienced surgeon under ocular anesthesia. Following the conventional CXL protocol ophthalmic riboflavin solution (Mediocross M; Avedro Inc, USA) was instilled into cornea for 30 minutes and ultraviolet-A was applied at $3 \mathrm{~mW} / \mathrm{cm}^{2}$ irradiance for 30 minutes with a Vega CBM X linker (CSO, Florence, Italy). Postoperatively, topical moxifloxacin, dexamethasone and artificial tears were administered four times a day for four weeks.

\section{Statistical Analysis}

The study data were analyzed using SPSS version 21.0. The normal distribution of the results was checked using the Shapiro-Wilk test. Categorical variables were expressed as numbers and percentages, and quantitative results were expressed as mean \pm standard deviation or median (2575\% IQR). Parameters at baseline and postoperative 24month follow-up were compared using the paired t test and the Wilcoxon paired test depending on the data distribution. A p-value of less than 0.05 was considered statistically significant.

\section{Results}

A total of 45 eyes of 34 patients were included in the present study. The demographics and clinical features of the study population are summarized in Table 1 . The mean age of the patients was $14.6 \pm 3.5$ years (10-17). A history of allergic symptoms was present in $67.6 \%$ of the patients. A majority of the patients had stage 2 and 3 keratoconus eyes (8.9\% stage $1,35.5 \%$ stage $2,51.1 \%$ stage $3,4.5 \%$ stage 4).

Table 1. Demographic data and baseline characteristics of the patients

\begin{tabular}{lc}
\hline $\mathbf{( n = 4 5 )}$ & Value \\
\hline Age (years) & $14.6 \pm 3.5$ \\
Mean \pm SD & $10-17$ \\
Range & \\
Gender (\%) & 52.9 \\
Female & 47.1 \\
Male & 67.6 \\
Allergic symptoms (\%) & \\
Keratoconus stage (\%) & 8.9 \\
1 & 35.5 \\
2 & 51.1 \\
3 & 4.5 \\
4
\end{tabular}

The mean refractive values, visual acuity and corneal parameters of the patients before and after CXL are summarized in Table 2. There was no significant change in spheric and astigmatic value at 24 months postoperatively. Compared to baseline, the mean SE was statistically significantly decreased at the 24-month follow-up $(p=0.016)$. 
There was a statistically significant improvement at the 24-month follow-up in UDVA (from $0.62 \pm 0.30 \log M A R$ to $0.11 \pm 0.06 \log M A R, p=0.003$ ) and CDVA (from $0.62 \pm 0.30$ $\log M A R$ to $0.11 \pm 0.06 \log M A R p=0.005)$. The mean $K 1, K 2$ and Kmean values were significantly lower than the preoperative values at the 24-month follow-up (from 47.38 $\pm 3.40 \mathrm{D}$ to $47.03 \pm 3.41 \mathrm{D}, \mathrm{p}=0.004$; from $51.30 \pm 3.80$ $D$ to $50.22 \pm 3.99 \mathrm{D}, \mathrm{p}=0.002$; and from $49.35 \pm 3.70 \mathrm{D}$ to $48.58 \pm 3.54 \mathrm{D}, \mathrm{p}=0.003$, respectively). The mean pachymetry value at the thinnest location remained stable postoperatively $(p>0.05)$.

Table 2. Refraction, visual acuity and topographic values before and after CXL $(n=45)$

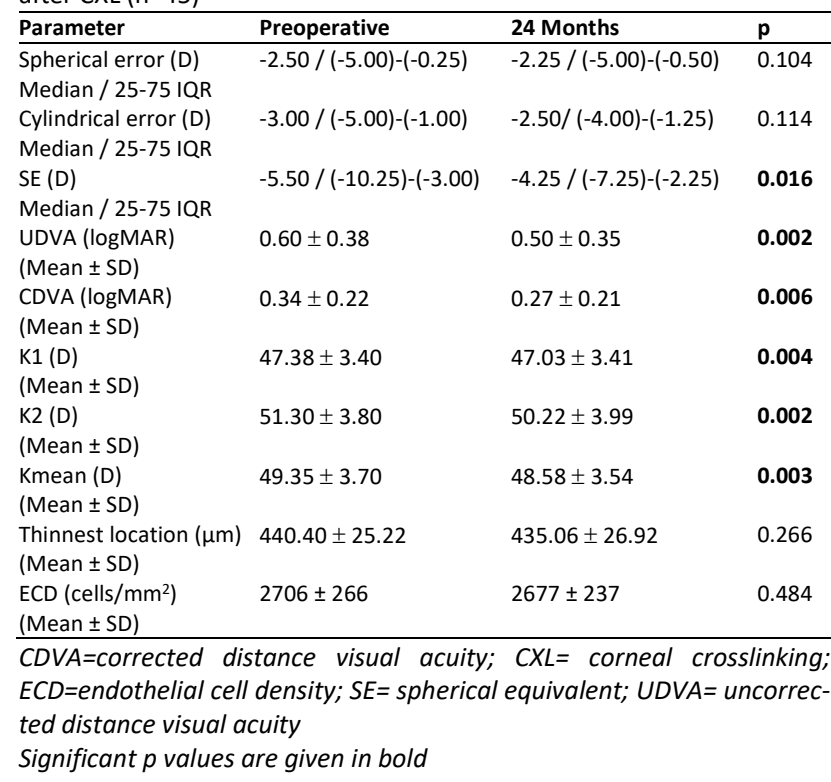

In this study, an increase in Kmean $1 \mathrm{D}$ and above after the treatment was defined as progression, a decrease of $1 \mathrm{D}$ and above was defined as regression, and a change of up to $\pm 1 \mathrm{D}$ was accepted as stabilization. Keratoconus progression, stabilization and regression percentages are shown in Figure 1. Kmean was stabilized in $67 \%(n=30)$ and regressed in $24 \%(n=11)$ of the eyes and progressed in $9 \%$ $(n=4)$ of the eyes at 24 months postoperatively.

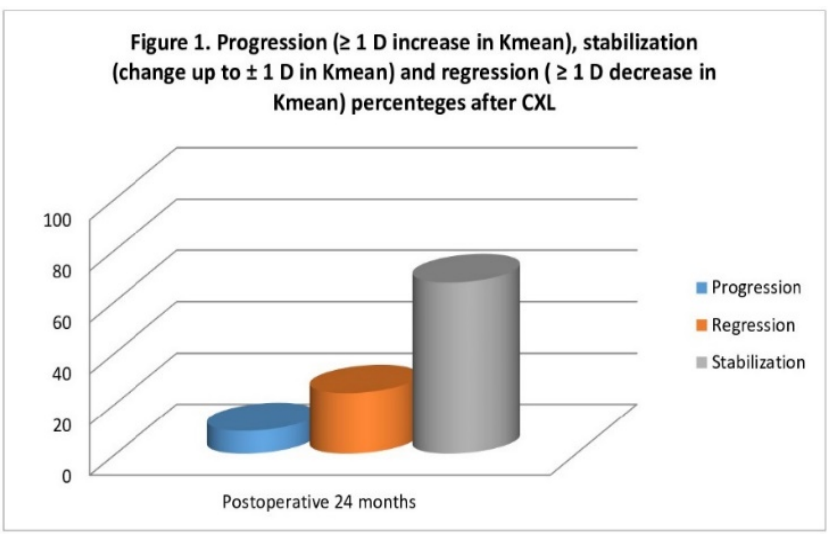

Fig 1. Progression, stabilization and regression percentages after CXL.
There was no significant change in ECD at 24 months after treatment $(p=0.484)$. Postoperative complications such as corneal haze and scar, endothelial cell damage, infectious and sterile keratitis were not found after CXL.

\section{Discussion}

This study evaluated the safety and efficacy of CXL on keratoconus progression in children. The results showed that patients with pediatric keratoconus have significantly higher UDVA and CDVA, and significantly reduced $\mathrm{K} 1$ and $\mathrm{K} 2$ values at 24 months after CXL. Furthermore, no corneal endothelial cell loss or major adverse events were observed after treatment.

The efficiency of CXL in keratoconus progression has been proven in many clinical trials in adult population and studies have shown an increase in visual acuity and a regression in keratometry values after treatment (7-9). However, contradictory results about the outcomes of CXL in different age groups have been reported in literature. Some studies have reported that there was greater improvement in both visual acuity and keratometry values in the pediatric age group than adults $(11,12)$. In contrast, other studies reported comparable and better functional and morphologic outcomes after CXL in adult populations (13-15). This difference could be explained by variations in mean age, keratoconus severity, CXL method and riboflavin content.

A previous study found no significant change in mean refraction, visual acuity and keratometry values in pediatric keratoconus patients at one-year follow-up (16). Another study reported significant improvement in CDVA and no significant change in keratometry 12 months after CXL in patients under 17 years of age (13). We demonstrated significant improvements in refraction, visual acuity and keratometry after CXL at the 24-month postoperative followup. Similar to our findings, significant improvement in CDVA and maximum keratometry was reported at twoyear follow-up after CXL (17).

Stabilization (67\%) and regression (24\%) of keratometry was seen in $91 \%$ of eyes at 24 months in this study. Previously, this rate was reported as $85 \%$ by Padmanabhan et al. in their pediatric study group two years after CXL (18). The progression rate was reported to range from $0 \%$ to $15 \%$ in previous studies. Our result was consistent with the literature.

In this study, we found no significant alteration in ECD at 24-month follow-up. Similar findings have reported by Vinciguerra et al. after CXL in a pediatric age group (4). No major complications were observed postoperatively; therefore, our findings can be interpreted as demonstrating that CXL is safe in pediatric patients.

The present study has some limitations. There are studies in literature evaluating factors such as age, baseline corneal thickness and keratometry that affect the progression of keratoconus after CXL (18-20). If an adequate sam- 
ple size had been reached, the comparison of these subgroups could have been added to the study. Another limitation was that the study had a single-center and a relatively small number of patients. Large-scale studies investigating the effectiveness of CXL in children would be helpful.

In conclusion, CXL has been shown to be safe and effective in stabilizing keratoconus progression, as well as improving visual acuity in a pediatric age group. Based on these findings, CXL can be used effectively to stop the progression of keratoconus in children. The efficacy and safety of CXL in the treatment of pediatric keratoconus should be investigated in longer follow-up studies with larger cohorts.

Ethical Approval: This study adhered to the tenets of the Declaration of Helsinki and was approved by the local Ethics Committee (Hatay Mustafa Kemal University non-interventional clinical research ethics committee Date:18/02/2021 Number:25/03) . An informed consent form was ob-tained from the parents

\section{Author Contributions:}

Concept: D.O.O., S.C.O.

Literature Review: D.O.O., S.C.O.

Design : D.O.O., S.C.O.

Data acquisition: D.O.O., S.C.O.

Analysis and interpretation: D.O.O., S.C.O.

Writing manuscript: D.O.O., S.C.O.

Critical revision of manuscript: D.O.O., S.C.O.

Conflict of Interest: Authors declared no conflict of interest.

Financial Disclosure: Authors declared no financial support.

\section{References}

1. Rabinowitz YS. Keratoconus. Surv Ophthalmol. 1998; 42(4):297-319.

2. El-Khoury S, Abdelmassih Y, Hamade A, Slim E, Cherfan $\mathrm{CG}$, Chelala $\mathrm{E}$, et al. Pediatric keratoconus in a tertiary referral center: incidence, presentation, risk factors, and treatment. J Refract Surg. 2016; 32(8):534-41.

3. Sabti S, Tappeiner C, Frueh BE. Corneal cross-linking in a 4-year-old child with keratoconus and Down syndrome. Cornea. 2015; 34(9):1157-60.

4. Vinciguerra $P$, Albe E, Frueh BE, Trazza S, Epstein D. Twoyear corneal cross-linking results in patients younger than 18 years with documented progressive keratoconus. Am J Ophthalmol. 2012; 154(3):520-6.

5. Leoni-Mesplie $S$, Mortemousque $B$, Touboul $D$, Malet $F$, Praud D, Mesplie N, et al. Scalability and severity of keratoconus in children. Am J Ophthalmol. 2012; 154(1):5662.

6. Wollensak G, Spoerl E, Seiler T. Riboflavin/ultraviolet-ainduced collagen crosslinking for the teratment of keratoconus. Am J Ophthalmol. 2003; 135(5):620-7.

7. O'Brart DP, Kwong TQ, Patel P, McDonald RJ, O'Brart NA. Long-term follow-up of riboflavin/ultraviolet $A(370 \mathrm{~nm}$ ) corneal collagen cross-linking to halt the progression of keratoconus. Br J Ophthalmol.2013; 97(4):433-7.

8. Ghanem RC, Santhiago MR, Berti T, Netto MV, Ghanem VC. Topographic, corneal wavefront and refractive outcomes 2 years after collgen crosslinking for progressive keratoconus. Cornea. 2014; 33(1):43-51.
9. Raiskup-Wolf F, Hoyer A, Spoerl E, Pillunat LE. Collagen crosslinking with riboflavin and ultraviolet-A light in keratoconus: long-term results. J Cataract Refract Surg. 2008; 34(5):796-801.

10. .Krumeich JH, Kezirian GM. Circular keratotomy to reduce astigmatism and improve vision in stage I and II keratoconus. J Refract Surg. 2009; 25:357-65.

11. Caporossi A, Mazzotta C, Baiocchi S, Caporossi T, Denaro R. Age-related long-term functional results after riboflavin UV A corneal cross-linking. J Ophthalmol. 2011; 2011:608041.

12. Soeters N, van der Valk R, Tahzib NG. Corneal cross-linking for treatment of progressive keratoconus in various age groups. J Refract Surg. 2014; 30(7):454-60.

13. Barbisan PRT, Pinto RDP, Gusmao CC, de Castro RS, Arieta CEL. Corneal collagen cross-linking in young patients for progressive keratoconus. Cornea. 2020; 39(2):186-91.

14. Vinciguerra R, Romano $\mathrm{M}$, Carnesasca $\mathrm{Fl}$, Azzolini $\mathrm{C}$, Trazza S, Morenghi E, et al. Corneal cross-linking as a treatment for keratoconus: four-year morphologic and clinical outcomes with respect to patient age. Ophthalmology. 2013; 120(5):908-16.

15. Uçakhan ÖÖ, Celik Buyuktepe T, Yavuz Z, Asbell PA. Pediatric versus adult corneal collagen crosslinking: longterm visual, refractive, tomographic and aberrometric outcomes. Curr Eye Res. 2021; 46(1):14-22.

16. Wise S, Diaz C, Termote K, Dubord PJ, McCarthy M, Yeung $\mathrm{SN}$. Corneal cross-linking in pediatric patients with progressive keratoconus. Cornea. 2016; 35(11):1441-3.

17. Toprak I, Yaylali V, Yildirim C. Visual, topographic, and pachymetric effects of pediatric corneal collagen crosslinking. J Pediatr Ophthalmol Strabismus. 2017; 54(12):84-9.

18. Padmanabhan $P$, Rachapalle Reddi $S$, Rajagopal $R$, Natarajan $R$, Iyer $G$, Srinivasan $B$, et al. Corneal collagen crosslinking for keratokonus in pediatric patients-long-term results. Cornea. 2017; 36(2):138-43.

19. Sarac O, Caglayan M, Cakmak HB, Cagil N. Factors influencing progression of keratoconus 2 years after corneal collagen cross-linking in pediatric patients. Cornea 2016; 35(12):1503-7.

20. Ozer MD, Batur M, Mesen S, Tekin S, Seven E, Yasar T. Comparison of the efficacy of accelerated corneal crosslinking in different pediatric age groups having progressive keratoconus. Int Ophthalmol. 2020; 40(10):2651-8. 